To this is attributed its beneficial action in mitral disease and in some cases of bronchitis and pneumonia.

No mere mechanical relief to the hearb can, however, explain the observed effects. We have seen that venesection in some cases appears to influance in a favourable manner the progress of specific diseases, both acute and chronic, probably by heightening the natural resistance of the tissues; that it helps to restore the balance of the circulation and the normal distribution of the blood by a dilator effect on the arterial system; that a small venesection may have a powerful and apparently disproportionate influence, not only in quieting the circulation, but the nerve centres also. This is witnessed in uræmic coma or convulsions and in the crises of pain and dyspnoe in aneurysm. We have noticed that excessive blood pressures have been more or less permanently reduced by venesections far too small to produce such effects in a direct manner. Such facts as these suggest that the respiratory and vaso-motor centres are concerned in these actions ; and that there are, in truth, morbid states of the circulation and the nervous system, both acute and chronic, which are in some unknown manner peculiarly sensitive to a slight reduction in the amount of the circulating blood.

Wimpole-street, $W$.

\section{THE PREVENTION OF ANTHRAX INFEC- TION DUE TO IMPORTED HIDES AND SKINS.}

(THE SEYMOUR-JONES FORMIC-MERCURY PROCESS.)

By CONSTANT WELLS PONDER, M.D., D.P.H. CANTAB., M R C.S. ENG., L R.C.P. LoNd.,

SECOND STUDENT, JOHN LUCAS WALKER TRUST ; IJACTERIOLOGIST AT THE LEATHERSELLERS' COMPANY'S TECHNICAL COLLEGE, BERMONDSEX.

WORKMEN who handle imported hides and skins run a certain risk of contracting the dangerous disease set up by the spores of B. anthracis. Though goods from certain countries, such as China and the Straits Settlements, have a bad reputation in this respect, from our knowledge of the conditions under which the disease has been contracted we can scarcely describe as absolutely free from blame those of any particular country. The number of cases reported is not large-roughly, one case occurs annually among every 1600 engaged in tanning, and about 1 in 7000 die from the disease every year, but its dramatic acuteness and high mortality give it an importance not indicated by the actual figures.

Many attempts have been made to find a method suitable for disinfecting hides, but none hitherto suggested has survived the criticism of bacteriological or technical experts ; either the process has failed to destroy the spores, coated as they may be by protective albuminoid material, or, on the other hand, it is condemned for its injurious effect on the hide and skin substance.

In this paper I wish to bring before the notice of the profession a method for which it is claimed that effective disinfection is brought about at a reasonable cost without damage to the material. This method is due to the suggestions of Mr. Alfred Seymour-Jones of Wrexham, a practical tanner and leather trades chemist. Before discussing Mr. SeymourJones's method, however, it will be as well to consider briefly the manner in which hides and skins convey the infection, the state in which they are imported, and the general conditions under which workmen contract the disease, matters with which I have dealt more fully elsewhere. ${ }^{1}$

I think it extremely probable that in hides and skin, as Dr. Eurich ${ }^{2}$ has so plainly demonstrated to be the case in imported wool, the spores occur in their most dangerous form in blood and blood-stained material which has dried on the surface of the fur and skin ; it certainly is fair to assume as a hypothesis that spores protected in this way are as resistant to disinfection as any, and if we are able to deal with these effectually there is not much danger from others that are present on the skin under slightly different conditions. In the animal dying from anturax there is every

1 C. W. Ponder: A Report to the Worshipful Company of Leathersellers on the Incidence of Anthrax amongst those Engaged in the Hile, Skin, and Leather Industries, with an Inquiry into Certain Measures siming at its Prevention. Published by the Company, 1911. 2 F. W. Eurich : Annual Reports of the Bralford Anthrax Investigation Board, 1906-10. chance of the skin and fur becoming contaminated with blood-stained discharges, which after drying are liable later on to form an infective dust; there is much evidence to show that spores do not form in the substance of the skin.

When the skin is removed from the animal it may be treated for preservation in several ways; we may divide these roughly into two classes. 1. Methods in which the skin is dried in the air or sun, and in which certain earths or chemical materials may or may not be rubbed in to prevent putrefaction. (The chemical materials in use may be assumed to have no action on the spores of $B$. anthracis, as infection from skins so treated has often taken place.) These methods may be called "dry-curing." 2. Methods in which the skin is soaked or treated with common salt or a strong solution of brine, so that, owing to the hygroscopic nature of this substance, real drying does not take place. This method of cure is known as "wet-salting."

Now experience has shown that very few, if any, cases of anthrax have been traced to infection from "wet-salted" goods, and the reason for this may be fairly easily conjectured. In the first place, they are not dusty, and so the spores are not so likely to gain access to the most susceptible parts-the face and neck. (Contrary to the general belief hides and skins are practically never carried on the shoulder.) Then, again, the spores under damp conditions may tend to develop into bacilli and perish, as has been suggested by Spear. ${ }^{3}$ We must, however, bear in mind that "wet-salting" is not the usual method employed in places such as China, where anthrax-infected skins are likely to be more common from the fact that no control is exercised over infected stock, but in places like Australia and North and South America, where anthrax-infected skins are not so likely to be bronght in for cure.

Why, it may be asked, has not "wet-salting" become the usual method of cure? The answer is because the process mast be carried out immediately after flaying the animal and it is difficult and expensive to carry salt to the semi-civilised places from which many skins are brought down; the freight of " wet-salted "goods is rather higher as they naturally weigh more ; and, finally, the primitive methods of the natives are not easily changed. As a counter-balancing advantage to the increased cost, however, is the fact that "wet-salted" goods are better preserved, their condition and value can be more correctly estimated, and they are easier and safer to handle in the early processes of tanning. As a fact, no improvement in this direction is indicated by import statistics, the relative proportions having remained fairly constant during the last decade.

TABLE I.

\begin{tabular}{|c|c|c|c|}
\hline \multirow{2}{*}{ Year. } & \multicolumn{2}{|c|}{ Imports in hundredweights. } & \multirow{2}{*}{$\begin{array}{l}\text { Percentage } \\
\text { imported as } \\
\text { "wet-salted." }\end{array}$} \\
\hline & "Dry." & "Wet-salted." & \\
\hline $\begin{array}{lll}1899 & \ldots & \ldots\end{array}$ & 446,725 & 763,548 & 63 \\
\hline $\begin{array}{llll}1909 & \ldots & \ldots\end{array}$ & 463,993 & 737,602 & 60 \\
\hline
\end{tabular}

From the examinations I have made of dust, dirt, and blood-stained material taken from dry hides, I have come to the conclusion that the proportion infected is larger than one would have expected. For example, 25 samples of dirt, sc., were taken from dry hides lying exposed for sale in the Bermondsey hide wharves; no discrimination was used beyond choosing dirty and low-quality hides. Agar plates were made from emulsions in which non-sporing organisms had been killed, and from the first 31 satisfactory platesthat is to say, those which were not overgrown or showed hardly any growth-two undoubted colonies of B. anthracis were obtained. The finding of these isolated spores suggests that they were carried in contaminated soil rather than that the skin was taken from the carcass of an animal that had died from anthrax. It is interesting to note that one also very frequently met with organisms that were only dis. tinguished from $B$. anthracis after a careful examination of their cultural and pathogenic characters. From the abovementioned 31 plates 16 distinct types of anthracoid organisms were so obtained; these were indistinguishable from $B$. anthracis in the primary cultures.

3 J. Spear: Anthrax in London Ilides and Skins. Report of the Medical Officer to the Local Government Board, 1882. 
If any process of disinfection is to be completely effective it is obvious that it must be carried out at a stage before opportunities of infection arise. In connexion with hides and skins it is essential that the goods should be disinfected at a stage previous to their being unloaded from the vessels, for statistics show that workmen in dockyards and warehouses are even more frequently infected than are those who handle the skins after they reach the tanyard. Thus, of 113 cases of anthrax during the seven years 1903-09 that were considered to be due to handling hides or skins, 60 , a proportion of 53 per cent. of the total, occurred among those working in dockyard or warehouse, while only 42 , or 37 per cent., occurred among tannery workers; it would clearly be therefore only a half-measure to disinfect the goods in the tanyard.

Before export the goods are collected by shippers at the ports of shipment and are there roughly cleaned, sorted, and baled, so that if a simple process of disinfection could be devised, there should be no difficulty in carrying it out at this stage, and this being done, all the cases of anthrax in the country of import would be prevented. Many suppose that certain outbreaks amongst animals in this country are due to the food-stuffs becoming contaminated when carried in the holds of steamers, trucks, \&c., which have previously carried dry hides; if disinfection were carried out before shipment, this possible source of infection would also no longer exist.

To summarise the requirements of an effective disinfecting process for hides and skins :-

1. It must be capable of destroying the spores of $B$. anthracis when present on hides and skins under any of the conditions in which they may be supposed to occur naturally -e.g., when protected by blood dried hard.

2. It must not injure the hides or skins or interfere in any way with the subsequent processes by which they are converted into leather.

3. It should be simple, so that it can be carried out at the ports where the skins are collected and shipped.

4. It must not add considerably to the cost of the raw material.

5. It should not involve the use of substances of a nature dangerous or poisonous to those who have to carry it out.

\section{Mr. Seymour-Jones's "Formic-Meroury" Process for} Disinfeoting Hides and Skins.

The "Formic-Mercury" process consists in placing the dry hides for 24 hours in a "soak" which is made up to contain 1-2 per cent. of formic acid and 0.02 per cent. of perchloride of mercury and then " salting" them with sodium chloride. The action of the "soak" is to swell up the fibres of the hide by causing them to absorb water, the result being that the hide returns to a condition closely resembling that in which it was when taken from the animal's carcass. This swelling action also affects the dry albuminous matter which may be supposed to protect the spores, the perchloride of mercury therefore permeates the protecting material and its full action can be exerted. Moreover, as has long been known, the presence of the weak acid prevents the rapid deterioration of the germicide from the formation of insoluble albuminates. After the "soak," the "salting," by again abstracting water, converts the hides into a condition which differs very little from the "wet-salted" state of a hide which had been so treated immediately after flaying.

By this process, essentially simple, we have a combination of factors which would seem to act harmoniously towards accomplishing the desired disinfection. In the first place, a good deal of cleansing must take place; then the hides are converted into the " wet-salted" state, a measure in itself of extreme value; finally, the spore is attacked by the perchloride of mercury, the action of which is accentuated by the swelling and penetrating effect of the acid and by the fact that under these conditions its germicidal power is not minimised by the formation of insoluble albuminates.

Let us consider how this process meets each of the requirements which, as stated above, are demanded by an ideal disinfecting method.

1. Efficienoy.-Having followed the development of this process since its inception, I have had the opportunity of testing many combinations of different acids with perchloride of mercury and other salts on anthrax-infected materials and have satisfied myself that the action of this combination on the spores of $\mathbf{B}$. anthracis is very profound. It is unnecessary here to recapitulate these tests, and it is sufficient to say that they led to the adaptation of the strengths described below, and confirm the final results.

The method that I adopted is fully described in the report previously referred to; it was briefly as follows:-

Test preparations were made by cutting out pieces of dry hide to a given weight. In the centre of each piece a drop of blood freshly drawn was allowed to fall, and before it clotted a loopful of emulsified spores of $B$. anthracis, taken from a strain obtained from a cow dead from anthrax, was thoroughly incorporated. The preparation was then dried and kept some weeks until required. When disinfection was attempted the proportion of the fluid to the weight of the hide was always the same as it would be under practical conditions. After disinfection the clct could be easily removed with a scalpel from the hide and introduced under the skin of an animal. Introduction into a culture medium was not found to be a satisfactory indication of the vitality of the spores, even if the free perchloride of mercury were neutralised with ammonium sulphide. Control tests with untreated clots always caused the death of a guinea-pig in less than 48 hours.

The results of tests on animals, kindly conducted by Dr. Graham Smith at Cambridge, are given in the following table :-

TABLE II.-The Disinfecting Action of a Solution containing Perchloride of Meroury and Formzo Aoid on Anthrax Spores protected by Dried Blood on a Hide.

(Weight of pieces of hide, 2.5-3.0 grm.; fluid used in disinfecting each, 25 c.c.; temperature of room, $60^{\circ} \mathrm{F}$; t time of treatment, 24 hours ; soaked in brine, 24 hours.)

\begin{tabular}{|c|c|c|c|c|}
\hline 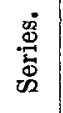 & Experiment. & $\underset{\dot{\Xi}}{\dot{\Xi}}$ & 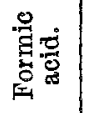 & Result. \\
\hline \multirow{2}{*}{1} & $\begin{array}{l}\text { Two guinea-pigs inocu- } \\
\text { lated with clot from } \\
\text { hide treated with brine } \\
\text { only (control). }\end{array}$ & - & - & $\begin{array}{l}\text { One died in } 36 \text { hours; } \\
\text { the other in } 48 \text {. In both } \\
\text { the appearances were } \\
\text { typical and anthrax was } \\
\text { confirmed by microscopi- } \\
\text { cal and cultural tests. }\end{array}$ \\
\hline & $\begin{array}{l}\text { Ten guinea-pigs inocu- } \\
\text { lated with clots from ten } \\
\text { hides treated by full } \\
\text { process. }\end{array}$ & $0.01 \%$ & $1.0 \%$ & $\begin{array}{l}\text { Nine survived. One died } \\
\text { after three days; the } \\
\text { a p pea ra n es were } \\
\text { typical and anthrax was } \\
\text { confirmed by microseopi- } \\
\text { cal and cultural tests. }\end{array}$ \\
\hline \multirow[b]{2}{*}{2\{} & $\begin{array}{l}\text { Two guinea-pigs inocu- } \\
\text { lated with clots from } \\
\text { hides treated with brine } \\
\text { only (controls). }\end{array}$ & - & - & $\begin{array}{l}\text { One died in } 36 \text { hours; } \\
\text { the other in } 48 \text {. Appear. } \\
\text { ances typical and } \\
\text { anthrax was confirmed } \\
\text { by microscopical and } \\
\text { cultural tests. }\end{array}$ \\
\hline & $\begin{array}{l}\text { Ten guinea-pigs inocu- } \\
\text { lated with clots taken } \\
\text { from ten hides which } \\
\text { had undergone full } \\
\text { process. }\end{array}$ & $0.02 \%$ & $1.0 \%$ & $\begin{array}{l}\text { Six survived with no ill- } \\
\text { effects. Hour died ; one } \\
\text { after } 6 \frac{1}{2} \text { days, one after } \\
7 \frac{1}{2} \text { days, and two after } 9 \\
\text { days. Anthrax con- } \\
\text { firmed by tests in every } \\
\text { case. }\end{array}$ \\
\hline \multirow{3}{*}{3\{} & $\begin{array}{l}\text { One guinea-pig inocu- } \\
\text { lated with clot taken } \\
\text { from a hide treated with } \\
\text { brine only (control). }\end{array}$ & - & - & $\begin{array}{l}\text { Died in } 36 \text { hours. Typical } \\
\text { appearances of anthrax. } \\
\text { The disease was con } \\
\text { firmed by microscopical } \\
\text { and cultural tests. }\end{array}$ \\
\hline & $\begin{array}{l}\text { Nine guinea-pigs inocu- } \\
\text { lated with clots taken } \\
\text { from nine hides treated } \\
\text { by the full disinfecting } \\
\text { process. }\end{array}$ & $0.1 \%$ & $1.0 \%$ & $\begin{array}{l}\text { All survived with no } \\
\text { ill-effects. }\end{array}$ \\
\hline & $\begin{array}{l}\text { Two guinea-pigs into each } \\
\text { of which clots from ten } \\
\text { hides which had gone } \\
\text { through the full dis- } \\
\text { infecting process were } \\
\text { inoculated. }\end{array}$ & $0.1 \%$ & $1.0 \%$ & $\begin{array}{c}\text { Both survived with no } \\
\text { ill-effects. }\end{array}$ \\
\hline
\end{tabular}

We see in these tests that using a 0.1 per cent. solution of $\mathrm{HgCl}_{2}$ in what amounts to 29 tests on guinea-pigs the clots were disinfected in every case. When 0.02 per cent. $\mathrm{HgOl}$ was used in ten tests six clots were disinfected, whilst in the other four the spores were so altered that the death of the guinea-pigs only took place after about a week or more. With 0.01 per cent. $\mathrm{HgCl}_{2}$ in ten tests the clots were disinfected nine times, but in one the guinea-pig died after only three days.

It would therefore appear that to ensure perfect safety one should recommend that a strength of 0.1 per cent. $\mathrm{HgCl}_{8}$ (1 in 1000) be used. I think, however, that this is unnecessarily strong, for it must be remembered that one cannot 
decide what strength of a disinfectant is appropriate for practical purposes by an opinion based on laboratory tests alone. Other considerations, such as expense, must be carefully taken into account. I am personally of the opinion that the most suitable strength to use would be 0.02 per cent. $\mathrm{HgCl}_{2}$ (1 in 5000); I base this opinion on the following points :-1. The tests are as stringent as I could devise; in actual practice many of the conditions would be more in favour of the disinfection than in my tests-e.g., the higher temperature of the water in places like India, China, and the Straits Settlements. 2. The other factors in the disinfection-namely, the cleansing and the conversion into the "wet-salted" state-I regard as more important even than the actual destruction of the spores by perchloride of mercury. 3. Though the spores treated with 0.02 per cent. $\mathrm{HgCl}_{2}$ in a small proportion of cases were able to kill a guinea-pig after the delayed period of seven days it does not follow that they would even set up the disease in man, who, there is evidence to show, is much more resistant to anthrax than the guinea-pig.

Little need be said as to the way in which this process is calculated to meet the further requirements of an ideal disinfecting method.

Injury to hides and skins. - In the opinion of the leading leather trades chemists and practical tanners who have experimented with this process no damage whatever is done to the goods, but, on the contrary, they are better preserved, easier to evaluate, and less likely to give trouble at the early stages of tanning since they are better preserved against putrefaction. The damage which $\mathrm{HgCl}_{2}$ by itself does to the skin is prevented, since the formation of insoluble albuminates is inhibited by the acid which is present.

Application.-The process is a simple one, and it is clear that it could be carried out by unskilled labour in the ports of shipment. The necessary materials for the "soak" could be sent out in a concentrated state.

Cost.-Mr. Seymour-Jones estimates that the total inclusive cost of the process per hide would not exceed $3 \cdot 75 d$. even in remote ports. When it is remembered that the value of a raw hide is roughly $£ 1$, the extra cost of disinfection cannot be considered appreciable. The process is not patented.

Danger to vorkmen. - There would be no danger in using $\mathrm{HgCl}_{2}$ in the required dilutions; the goods would need very little handling.

A practical method having been suggested, how can its application be ensured to those goods which constitute a potential danger to our workmen? The American Government has led the way by making it illegal to import hides and skins into their country unless accompanied by a Consular certificate stating that there is no anthrax among the cattle in the district from which they are exported or that the goods have been submitted to a disinfecting process. As regards the first requirement, it is ineffective because the skins come to the port from far inland, whilst the second is useless because no effective applicable disinfecting process is suggested.

Civilised Governments should forbid the importation of hides or skins unless either (1) they have been submitted to the ordinary "wet-salting" process immediately after flaying; or (2) if cured by drying they have been converted back to the "wet-salted" state by the "formic-mercury" process before leaving the country of export. If such regulations were adhered to I am convinced we should hear no more of anthrax amongst the dock labourers and warehousemen in Bermondsey and Liverpool, nor of those sporadic cases which are continually cropping up in the tanneries in different parts of the country.

Pathological Laboratories, Cambridge University.

Service for Medical Workers in Brighton.The annual special service for medical practitioners, nurses, and others engaged in medical work was held in Brighton parish church on Sunday evening, Oct. $22 n d$. The Rev. Dr. Upcott, head-master of Christ's Hespital, was the special preacher. In the course of his sermon he declared that the occupations which those in his congregation so well represented that evening were the purest and noblest in mankind if used in the right way and spirit, for it was pre-eminently a life of service. The collection was in aid of the Queen's Nurses' Fund.

\section{THE TREATMENT OF BUBONIC PLAGUE BY THE IMMEDIATE INCISION \\ OF THE GLANDS.}

BY V. B. NESFIELD, F.R.C.S. FNG., CAPTAIN, I.M.S. ; DEPUTY SANITARY COMMISSIONER, FIRST CIRCLE UNITED PROVINCES OF AGRA AND OUDH.

WIIEN plague first appeared in Bombay in 1896, owing to mistakes in diagnosis, plague glands were occasionally removed. The patients were found to improve greatly for a few days, but ultimately invariably died from plague septicæmia. For this reason the removal of plague glands has been strongly condemned.

In 1905 I published the case (Indian Medical Gazette) of a Sowar of the 6th Bengal Cavalry who developed plague in Benares. On arrival in camp he fell off his horse and was found to have a large painful gland in the left groin. His temperature was $103.4^{\circ} \mathrm{F}$. and his pulse was fast, weak, and dicrotic. He had severe headache and some delirinm. The bubo had not been noticed six hours previously. An incision was made into the gland, which cut like a raw potato, and serum and blood escaped which showed swarms of the typical bipolar-staining bacilli. Iodine lotion ( 1 drachm of tinct. iodi to 2 ounces of water) was put into the wound, and a dressing soaked in this lotion applied. Two hours later the headache had disappeared, the temperature was $99^{\circ}$, and the patient was much better. Two days later the temperature rose again, but fell on opening the lips of the wound with a director. The patient recovered, and was able to continue his journey in three weeks' time. The case was a most severe example of bubonic plague. The gland was incised with the object of setting free the enclosed toxins.

During the severe plague epidemic in Lucknow in $1907 \mathrm{I}$ treated 87 cases of plague in the cantonment. Sixty-two of these cases were bubonic and 25 pneumonic, septicæmic, and what might be termed splenic. All the bubonic cases (Lucknow cantonment) were treated by the immediate incision of the swolien glands. By this method the great majority of the truly bubonic cases seen within 48 hours of the appearance of the buboes recovered. But it should be noted that some people dead of the disease were seen for the first time in their houses, having died overnight. so that those brought in alive to hospital with buboes may be looked upon as showing some resistance to the disease. Of the 62 cases treated in this way eight died and 54 recovered, giving a mortality of only 15.3 per cent. A few of these were old-standing cases, and would probably have recovered without treatment, but some were hopeless on admission, and some were picked up miles away from their homes, having wandered during the night; these wandering cases generally died, so that a mortality of only 15.3 per cent. is remarkably good, and I believe better than any recorded. Surgeon-Captain Thomson gave a mortality of 62.7 for cases with buboes, and 78.6 for cases without palpable buboes in the Parel hospital in 1896-97.

There was every opportunity for studying these cases very thoroughly, as many of them were private servants, and notice was frequently given on the first sign of fever, and thus it was possible to see them from the beginning. The special feature of the bubonic cases was a one, two, or three days' fever, with rambling speech at night, restlessness, headache, backache, and vomiting, together with a normal or sabnormal pulse tension. During this stage these cases resembled ordinary Indian fever, which one usually calls malaria, but with the difference that in malaria the pulse tension is high during the fever and there is no marked restlessness, headache, or rambling speech and there is sweating on remission.

After a day or so of this preliminary fever a large painful gland suddenly appeared in the groin, axilla, neck, behind the internal malleolus, the popliteal space, or behind the internal condyle of the humerus. The condition of the patient now became acute, the delirium very marked, headache very severe and the pulse very fast and dicrotic. Without treatment death usually results in thease cases in from 3 to 48 hours.

Professor R. T. Hewlett in his " Manual of Bacteriology" states that 70 per cent. or more of the bubonic cases begin with the two or three day's' initial fever. 